\title{
Advantageous of Volunteerism Values for Indonesian Community and Neighbourhoods
}

\section{Muhammad Mona Adha*}

Civic Education, Universitas Lampung, Lampung, Indonesia

\section{A R T I C L E I N F O}

Article history:

Received 20 February 2019

Received in revised form

10 March 2019

Accepted 30 April 2019

Available online 27 May 2019

Keywords:

community; Indonesian;

neighbourhoods;

volunteerism values

\section{A B S T R A C T}

The skills and participation of citizens are urgently needed for progress and prosperity in the community. Volunteerism opens opportunities for each individual to participate and contribute based on the knowledge and experience he has had in previous voluntary activities. Qualitative research implemented on this research, and ethnography method to explore the cultural background and young people engagement. Young people participation in voluntary activity has a positive impact on building community solidarity that strengthens togetherness and kinship. Sympathy and empathy are strengths in increasing individual motivation in voluntary activities. Volunteerism creates space for interaction and communication between individuals involvement in social activities. Social capital that runs well will bring about social welfare, this can be started from the involvement of individuals called active citizenship. The implications from the research are: 1) community need some positive activity and opportunity to engage; 2$)$ the more young people engage with the social activities the more they are trained and experienced. 


\section{Introduction}

Every Indonesian has a pride of being a citizen of the Indonesian Nation and moving forward to the development for the future (Purdey, 2017). Since the end of the Second World War, Indonesian society was open to the concept of volunteerism brought by other nations at that time. The participation of other nations in voluntary activities is very helpful in developing community life activities (Adha, 2019a; Adha et al., 2019). At present voluntary activities in Indonesia have developed very rapidly and are varied, characterized by the many voluntary activities carried out by young people in various activities in the community (Adha, et al., 2018). Voluntary activities carried out by individuals are to provide skills, knowledge, and experience for the volunteers themselves (Adha, 2018; Purdey, 2017; Packham, 2008) for the experiences gained can be implemented in the activities of community life.

Every individual and society has the duty and responsibility to participate in the activities of daily life (Lei and Zhao, 2012). Interaction and communication in the community environment, especially through events can unite between groups of people in strengthening social cohesion (Rao, 2001). Festival events have a function or benefit in developing social relationships (Everett and Parakoottathil, 2016), because in the festival there are several elements such as participants (performers), festival organizers, visitors, volunteers, government, and other parties involved ( Johansson and Toraldo 2015).

Philosophically, volunteerism is a concept of help-help without expecting rewards for money or gifts (Purdey, 2017). Pure volunteerism arises from the motivation in an individual to participate in an activity (Packham, 2008). The positive impact of voluntary activities carried out by each volunteer is discipline, a better attitude change, empathy, sympathy. The concept of volunteerism that is carried out in reality provides a good experience in person and becomes a capital for one's future in life activities including career. The implementation of mutual assistance becoming part of the life activities in Indonesian community, many Indonesians see gotong royong as a characteristic of the Indonesian national identity and to strengthen Bhinneka Tunggal Ika (Unity in Diversity) (Adha, 2015).

Packham explained some of the benefits or impacts that are useful for himself personally (the volunteers involved) and the community. The following are the purpose of benefits identified by Packham: Voluntary work; Voluntary engagements capacity within communities and neighborhoods contributes to social and individual well being; Social well being contributes to social cohesion and a reduction in crime, antisocial behavior; Engagement in voluntary activity as part of a group can be empowering and transformational experience leading to change and improvement (e.g. as part of a pressure or campaign group); Voluntary activity, particularly at the neighborhood level, can improve the delivery of services and impact of initiatives at local levels; Active involvement increases civic and civil engagement, and improves levels of involvement in governance; Engagement of citizens in policy making can be enabled more effective and efficient delivery of services; Enforced community involvement can contribute to society and do good, for example work done by students, refugees and asylum seekers (Packham, 2009), especially school can contribute to enhance morality from every individual (Abidin et al., 2015)

Freedom of expression, work, and creativity today has encouraged more participation from citizens in various fields of life. Therefore, the Indonesian people become more critical and open to change, especially those who are involved in engaging in various patterns of activities that reflect themselves as active citizens. In the current conditions of social change in society, as active citizens there will be sensitivity to themselves such as: concern for the environment, cleanliness, information development, and play a role in community activities. Working together in the concept of volunteerism in society must be done without seeing the status or position of a person, all are the same to make a change.

\section{Methods}

This research was conducted in Bandar Lampung, Lampung Province. There are several reasons and considerations in selecting a research location. First, the Krakatau Festival event was held in Bandar Lampung City since 1990 and has become the flagship program of the Lampung Provincial Government. Second, The Krakatau Festival is a cultural festival that is attended by all levels of Lampung society and delegates / representatives from cultures outside Lampung. This cultural event has become a part of the daily activities of the people of Lampung and always has a positive social impact in the Krakatau Festival journey until the XXVII festival in 2017.

Subjects in this study included the Head of the Lampung Province Tourism Office, the Head of Marketing Division of the Lampung Province Tourism Office, the organizing committee which was a member of the field of the Lampung Provincial Tourism Office. Other research subjects are stakeholders, representatives of the community in this case are initiators of the Krakatau Festival (including as 
Lampung cultural figures), journalist, bloggers, visitors, event participants, and volunteers involved in the XXVII Krakatau Festival.

This research method was carried out using descriptive method with ethnographic approach. Ethnography focuses on groups that share the same culture. Ethnography involves extensive observations of the group, often through participant observation, whose researchers immerse themselves in the daily lives of the community, observe and interview participants in the group. Ethnographers study the meaning of behavior, language, and interaction among members of the same cultural group (Cresswell, 2008).

Based on research methods and approaches, since 2016 observations have been made at the XXVI Krakatau Festival. Observations are made to follow the development of information, preparation and implementation of the Krakatau Festival. 2016, the initial information also comes from newspapers, magazines, and the results of meetings with several parties related to the festival.

In 2017, researchers again conducted observations, interviews, and directly participated in the XXVII Krakatau Festival. In the implementation of the Krakatau Festival in 2017 created collaboration between the provincial government, the organizing committee, stakeholders, the community, event participants, event organizers, and volunteers. This research explores directly to find out how the participation of the community and volunteers during the preparation and implementation of the peak of the Krakatau Festival. The researcher conducted observations and interviews in this festival to get data and information that supported the research conducted.

\section{Result and Discussion}

Each individual is given the freedom to choose and join in the voluntary activity that will be followed according to their respective interests. The participation of individuals to work voluntarily has different motivations and goals, but focusing on one goal is to work together to achieve the best results. Volunteer involvement as citizens is very important to develop personal abilities and develop people's lives (Packham, 2008). Volunteers must be able to actively participate and build cooperation, therefore they must be able to identify themselves addressing a problem, and be able to identify any steps to overcome the problem (Ord, 2007). Voluntary activities are able to improve the quality of communication, interaction and good relations among volunteers and between volunteers and the community so that they can increase the self-potential of volunteers as a provision of skills and experience in the future (Garner \& Garner, 2011).

Adopting Freirian or popular education models it is said that with education and patterns of development are solutions to thinking and finding solutions together to overcome problems. So in this case a thinking process is needed, activities are carried out by people who are creative and have abilities. Through education, participants who join as volunteers can identify various aspects and problems that are around and find out what steps of change will be implemented. This is what is expected through the education process in addressing the problems that are carried out together in groups / groups followed by critical problem reflection and analysis through dialogue / sitting together by prioritizing action and change (Stewart, 2008).

The concept of "action" or "active engagement" is characteristically translated more to informal education which is certainly different from formal education which is "directed, didactic, and non-experience approach to education." But on the other hand, "directed" is the nature of participants (volunteers), where volunteers as a first step is to choose what type of activities are followed then volunteers also compile and control both the concept of activities and the results of the activities carried out. Voluntary activity is expected to be very well organized, fulfilling the expectations of the volunteers themselves, has a "learning framework" picture that can be obtained from the surrounding conditions which provides opportunities for volunteers to participate (Packham, 2008).

There are three types of attributes or abilities that individuals are expected to have in participating in the community: (1) an open minded and reflective approach; (2) working from a firm foundation of values and assumptions; (3) the ability to engage in a process of continual review and professional inquiry (Brechin, 2000). The above opinion states that this will provide awareness to each individual to be able to continue to develop and be implemented from "critical practice" to "practice model." While an important component for individuals to better understand the overall process is to act from 'critical consciousness, then goes to 'critical theorizing,' then leads to 'critical action,' and 'critical reflection' (Butcher et al., in Packham, 2008). In the end, (Putnam, 2000) through "critical perspective makes a structural analysis of the causes of quality and justice, not one primarily based on the deficits of the individual. It therefore necessitates an approach where whole communities act in inclusive ways, which serve to bridge as 
opposed to bond and isolate. "A critical perspective can produce different analysis structures that not only observe individual behavior but are also used to see inequality and injustice.

Analyze the types or forms of voluntary activities that are related to bring benefits, then Putnam; Dewey in Packham (2008) said that voluntary work done should pay attention to these two important things, namely by doing / with whom (doing with) the volunteer will carry out its activities and for whom (doing for) the intended voluntary activities. For whom (doing for) a voluntary is done more related to the benefits for ourselves and the wider community (social contact), while with / with whom the voluntary activities we do are more related to the context of 'social capital' in this case more emphasis on using the network social or social connections to improve the value of relationships between individuals and better community groups and can increase mutual trust in values or norms adhered to (Putnam, 2000).

Encouraging the involvement or participation of community groups whether involved in a group or individually, in principle can have a very important impact on the lives of citizens. In particular, volunteerism supports the success of government programs in order to develop policies, structures, or improve government services (Packham, 2008). At present the broad participation of the community in various fields has become a growing trend throughout the world, especially "civic engagement." (Packham 2008). Individuals or groups of people who participate in voluntary activities indicate that the individual is capable of giving birth to a decision to involve himself despite the limitations of time and supporting resources (Richards-Schuster \& Pritzker, 2015). It is this sense of care for others that should be improved from time to time and it is evident that the current sense of caring for the wider community is felt by the support of information and technology to communicate and cooperate.

The opportunity to participate is wide open for anyone today. Active citizens are not merely learning about the "rules of the game" in the community and how to participate in the development of a model and structure, but citizens who are more broadly active in their activities in political literacy and empowerment, opening political cooperation where this is very important to create strong social relations and good social justice (Lister in Packham, 2008), and moral knowledge (Nurmalisa \& Adha, 2016). An active citizen is how everyone can support and develop social cohesion and community solidarity to strengthen people's lives at large and empower citizens individually. (Take Part in Packham, 2008).

The fact of revealing volunteerism is one of the sociological roots of the emergence of political parties as an important democratic institution. Volunteerism is the nucleus of civic virtue that encourages people to engage in social work both individually and together with other members of society. Volunteerism also unites people in an association based on concern for certain social problems, for example, those who care about the cleanliness of the environment, events and others. Volunteerism is not taken from birth, but must be nurtured through a variety of social contacts. Embedding civic virtue in a voluntary context, it is important to have the ability to organize themselves, gather support, mobilize volunteer groups, and provide support through concrete actions together, so that citizens can see the surrounding environmental conditions while finding treatment real.

\section{Conclusion}

Volunteering activities serve to invite members of community groups to contribute to building good relations between community groups. Voluntary activities can develop individual self-potential, skills, knowledge and personal experience. Volunteers are not paid or paid for the work they do, but with a strong self-commitment to help smooth a voluntary activity / program as a form of concern for the surrounding environment. Voluntary activities are very important in social relationships that strengthen norms and grow mutual trust with each other. the built social interaction and the existing social (environmental) structure will produce human values for community development. A skilled volunteer means knowing a lot of information that is not only about voluntary work but also about the community environment. Volunteers who are proficient have extensive knowledge and information, making it very easy for a volunteer to communicate with local residents, coordinate and carry out activities.

\section{Reference}

Abidin, R.F., Pitoewas, B. \& Adha, M.M. (2015). Peran Guru Pendidikan Kewarganegaraan Dalam Mengembangkan Kecerdasan Moral Siswa. Jurnal Kultur Demokrasi, 3 (1).

Adha, M. M. (2019). Pengembangan Keadaban Kewarganegaraan melalui Festival Krakatau. Disertasi. Sekolah Pascasarjana Universitas Pendidikan Indonesia: Tidak diterbitkan. 
Adha, M.M., Budimansyah, D., Kartadinata, S. \& Sundawa, D., (2019). Emerging Volunteerism for Indonesian Millennial Generation: Volunteer Participation and Responsibility. Journal of Human Behavior in The Social Environment, 29 (4): 1-17.

Adha, M. M., Hidayat, O. T., Susanto, E., \& Saylendra, N. (2018). Esensi Jiwa Volunteerism Warga Negara Muda Dieksplorasi dari Perspektif Keterlibatan Volunteer di Dalam Festival. Prosiding Seminar Nasional PPKn 2018 Seminar Nasional Penguatan Nilai-Nilai Kebangsaan Melalui Pendidikan Kewarganegaraan Persekolahan dan Kemasyarakatan. Laboratorium PPKn FKIP UNS, 7 Juli 2018.

Adha, M. M. (2015). Understanding the Relationship Between Kindness and Gotong Royong for Indonesian Citizens in Developing Bhinneka Tunggal Ika. The proceeding of the commemorative academic conference for the 60th anniversary of the 1955 Asian-African conference in Bandung-Indonesia. 46 June 2015.

Brechin, A ed. (2000). Critical Practice in Health and Social Care. London: Open University Press/Sage.

Cresswell. (2008). Educational Research: Planning, Conducting and Evaluating Quantitative and Qualitative Research Third Edition, New Jersey: Pearson Prentice Hall.

Everett, S. \& Parakoottathil, D. J. (2016). Transformation, Meaning Making and Identity Creation through Folklore Tourism: the Case of the Robin Hood Festival. Journal of Heritage Tourism, 13(1): 35-40.

Garner, J. T., Garner, L. T. (2011). Volunteering an Opinion: Organizational Voice and Volunteer Retention in Nonprofit Organizations. Nonprofit and Voluntary Sector Quarterly 40(5): 813-828.

Johansson, M., Toraldo, M. L. (2015). From mosh pit to posh pit: Festival imagery in the context of the boutique festival. Culture and Organization, 23(3): 220-237.

Lei, W., Zhao, W. (2012). Determinants of Arts Festival Participation: An Investigation of Macao Residents. Event Management, 16(4): 283-294.

Nurmalisa, Y \& Adha, M. M. 2016. Peran Lembaga Sosial Terhadap Pembinaan Moral Remaja Di Sekolah Menengah Atas. Jurnal Ilmiah Pendidikan Pancasila dan Kewarganegaraan, 1 (1): 64-71.

Ord. (2007). Youth Work Process, Product and Practice. Dorset: RHP.

Packham, C. (2008). Active Citizenship and Community Learning. United Kingdom: Learning Matters.

Purdey, J. (2017). Bridges of Friendship, Reflections on Indonesia's Early Independence and Australia's Volunteer Graduate Scheme. Australia: Monash University Publishing.

Putnam, R. D. (2000). Bowling Alone: The Collapse and Revival of American Community. New York: Simon and Schuster.

Richards-Schuster, K., Pritzker, S. (2015). Strengthening youth participation in civic engagement: Applying the Convention on the Rights of the Child to Social Work Practice. Children and Youth Services Review, 57: 90-97.

Stewart, A. (2008). Popular Education Workshop. Drawing on Partners, Training for Transformation. North West Citizenship Network Conference. Manchester Metropolitan University. Dublin: Partners. 